\title{
The Domestic Rice Value Chain in the Mekong Delta
}

Dao The Anh, Thai Van Tinh, and Nguyen Ngoc Vang

\section{INTRODUCTION}

Due to the almost continuous growth of yield and a much smaller growth in cultivated area, rice production in Vietnam has increased fourfold from 11.6 million $t$ in 1980 to a peak of 45.1 million $t$ in 2015 , dropping back to 42.8 million $\mathrm{t}$ in 2017 (Table 18.1). About $18 \%$ of milled rice production is exported, valued at USD 2.7 billion in 2017 and USD 2.2 billion in 2018, making Vietnam the third largest rice exporter globally after India and Thailand. The Mekong Delta accounts for about $56 \%$ of the total of 7.7 million ha cultivated, produces about $50 \%$ of total rice output, and contributes over $90 \%$ of rice exports. The export orientation of the

D. The Anh $(\bowtie)$

Vietnam Academy of Agricultural Sciences, Hanoi, Vietnam

T. Van Tinh

Centre for Agricultural Policy, Institute of Policy and Strategy for Agriculture and Rural Development, Ministry of Agriculture and Rural Development, Hanoi, Vietnam

N. Ngoc Vang

An Giang University, Long Xuyen, Vietnam

(C) The Author(s) 2020

R. Cramb (ed.), White Gold: The Commercialisation of Rice

Farming in the Lower Mekong Basin, https://doi.org/10.1007/978-981-15-0998-8_18 
Table 18.1 Number and type of value chain actors interviewed

\begin{tabular}{lc}
\hline Actors & No. interviewed \\
\hline Rice-growing households & 300 \\
Commune authorities where rice is grown & 20 \\
Millers in the production region & 70 \\
Traders in the production region & 60 \\
Wholesalers in urban areas & 50 \\
Traditional retailers & 85 \\
Modern retailers & 45 \\
Input and service providers (land preparation, seed, fertilizer, & 14 \\
extension, post-harvest) and provincial policymakers & \\
\hline
\end{tabular}

Delta is further highlighted by the fact that $70 \%$ of rice produced there is channeled through the export value chain.

There have been several studies of the rice export value chain (Tran 2010; Vo and Nguyen 2011), but the domestic rice value chain, representing $82 \%$ of production nationally and $30 \%$ of production in the Delta, has been understudied. This chapter reports a study of the domestic value chain in the Mekong Delta. The study aimed to (1) describe the rice value chain in the Delta, focusing on the domestic chain; (2) conduct economic analysis of the actors in the rice value chain; and (3) examine the impact of government policies on the rice value chain (Fig. 18.1). ${ }^{1}$

\section{Methods}

The approach used in the study followed Kaplinsky and Morris (2000). The production area studied comprised 20 communes in An Giang and Hau Giang Provinces, with an average of 7922 rice producers per commune. ${ }^{2}$ The combined production capacity of these provinces in 2012 was 5.12 million $t$ of paddy, accounting for $21.1 \%$ of the total output of the Delta region (GSOV 2013). The consumption area studied included Can Tho and Ho Chi Minh Cities. These were the two largest cities in the region, with an average demand of 1.18 million $t$ of rice per year.

We collected information using structured questionnaires for all the actors involved in the value chain (Chen et al. 2013). Actors were randomly selected in the research areas to ensure representativeness. The main actors were classified according to the scale of their operations. Farmers were classified as small (<l ha), medium ( $1-2$ ha), and large 


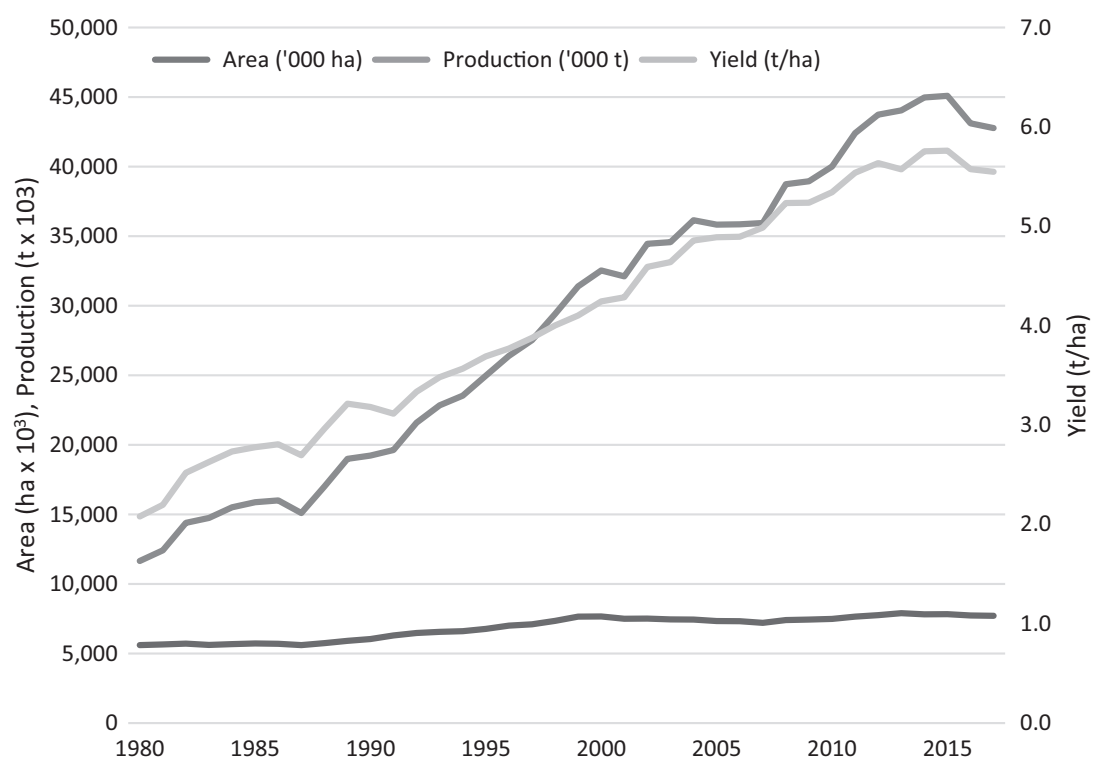

Fig. 18.1 Area, yield, and production of rice in Vietnam, 1980-2017. (Source: FAOSTAT)

( $>2$ ha). Rice mills were classified as small $(<1$ ton/hour); medium (1-5 t/hour); large ( $>5 \mathrm{t} /$ hour); and milling/polishing plants. Descriptive statistics were used to compare means and proportions for each category of actors.

\section{Overview of the Rice Value Chain in the Mekong DELTA}

In 2012, there were about 1.46 million rice farmers in the Mekong Delta cultivating about 4.1 million ha per year (given that rice is cropped 2-3 times per year in the Delta). Production of paddy was 24.6 million t, including short-term aromatic varieties (such as Jasmine 85, VD20, and ST5), short-term non-aromatic varieties (such as IR50404, VND95-20, and OM 576), and medium-term varieties (such as IR29723, IR42, and traditional local varieties). Farmers obtained production inputs such as fertilizers, pesticides, and farm equipment through a region-wide system 
of agricultural material stores and agencies, distinct from the traders and processors who handled the harvested product. There are now more than 100,000 millers and polishers operating in the region, of which up to 150 have been certified as rice exporters. Traders, wholesalers, and retailers operate through many different distribution channels in a widespread market (VFA 2012).

As illustrated in Fig. 18.2, the export value chain accounts for $70 \%$ of rice production in the region. This chain includes three channels: (1) a direct channel, in which paddy is sold by farmers to the exporting firms for milling and polishing, accounting for only $4 \%$ of exports; (2) a two-tier channel, in which paddy is sold by farmers to traders who bring it to the exporters for milling and polishing, accounting for $81 \%$ of exports; (3) a three-tier channel, in which traders sell paddy to the mills who sell rice to exporters as loose rice, accounting for $15 \%$ of exports.

The domestic rice value chain accounts for $30 \%$ of rice produced in the region. Wholesalers and retailers obtain rice from three sources: (1) from

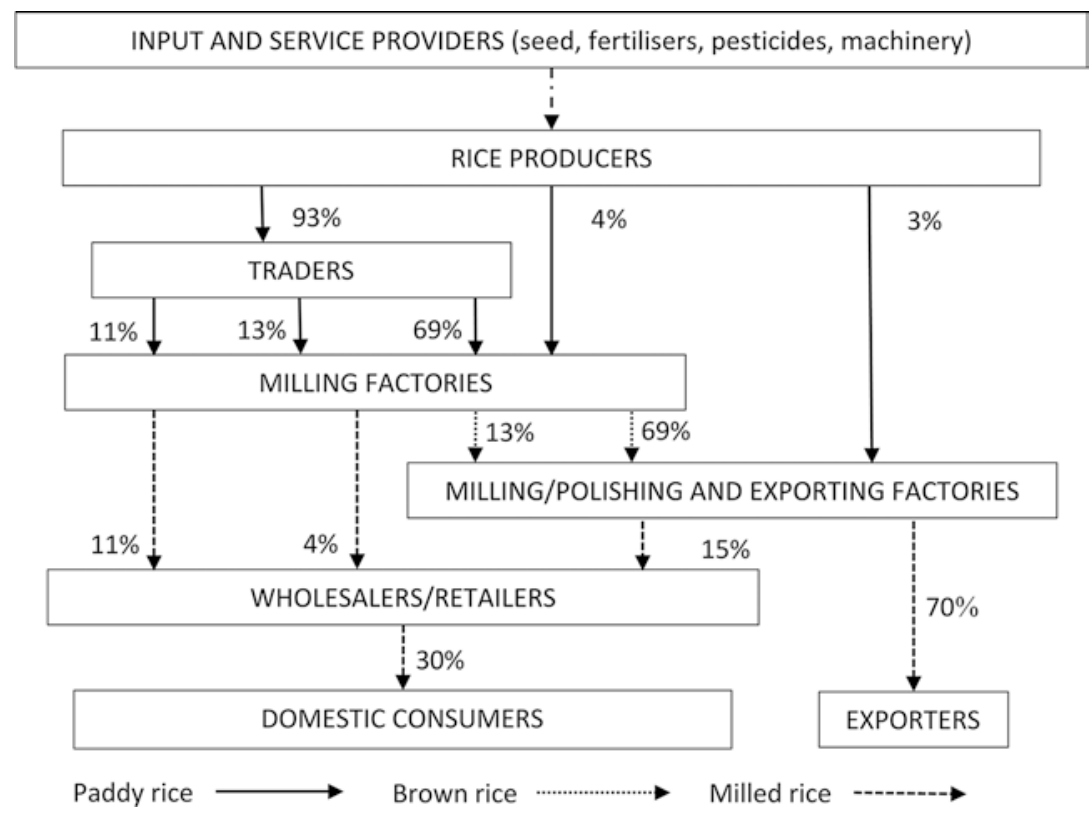

Fig. 18.2 Rice value chain in Mekong Delta 
traders who buy paddy from farmers and have it milled for local consumption, mainly in the vicinity of the mill (37\% of rice supplied to domestic consumers); (2) mills that supply rice for urban areas (13\%); and (3) large milling and polishing firms that supply the cities (50\%). In 2010, about 1.86 million $t$ of paddy were imported from Cambodia into the Mekong Delta area (of which $90 \%$ was the high-quality Mien variety), mainly for the domestic market (Purcell 2010). This stream is not considered here.

\section{Analyzing the Actors in the Rice Value Chain}

\section{Input and Service Providers}

(1) Production supplies. In the Mekong Delta, as noted above, production inputs are provided through a system of agricultural stores and agencies. According to the 2012 survey, each commune had on average four input supply stores for farmers. This delivery system was highly organized, with large agencies distributing inputs to smaller shops which in turn distributed inputs throughout the communes and villages. The large agencies were also a conduit for technical advice to input suppliers and farmers.

The producer survey found that $100 \%$ of respondents purchased inputs from a store near their homestead (Table 18.2). The main reasons for their choice of supplier were the quality of the inputs and that they could defer payment, implying the provision of short-term store credit. This was

Table 18.2 Status of input use by farmers in study area $(n=300)$

\begin{tabular}{lllll}
\hline & Small farms & Medium farms & Large farms & All \\
\hline $\begin{array}{l}\text { \% buying from store near house } \\
\text { Reason for selecting input supplier }\end{array}$ & 100.0 & 100.0 & 100.0 & 100.0 \\
$\begin{array}{l}\text { Regular customer } \\
\text { Short distance }\end{array}$ & 15.7 & 42.7 & 86.3 & 48.2 \\
Lower prices & 31.0 & 31.3 & 28.8 & 30.3 \\
Quality guaranteed & 31.5 & 15.7 & 11.3 & 19.5 \\
Payment can be delayed & 100.0 & 100.0 & 100.0 & 100.0 \\
Satisfaction with input supply & 100.0 & 100.0 & 98.5 & 99.5 \\
High & 89.4 & 86.5 & 87.2 & 87.7 \\
Moderate & 10.6 & 13.5 & 12.8 & 12.3 \\
Low & 0 & 0 & 0 & 0 \\
\hline
\end{tabular}

Source: Producer survey, 2012 
related to their reasons that the store was in close proximity and they were regular customers. Farmer satisfaction was high (about 88\%) across all size classes. However, only $25-45 \%$ of the farmers interviewed used certified rice seeds: most used seeds retained from their previous crop. ${ }^{3}$

(2) Machinery services. All stages of rice production in the Mekong Delta from land preparation to post-harvest operations were mechanized to a degree. In particular, land preparation and harvesting were entirely mechanized. Commune-level data for the 20 communes in the survey showed that the two-wheel tractors used for land preparation (and other purposes) were available at an average density of three tractors per 100 ha (Table 18.3). Given a capacity of 1.5 ha/day, these tractors could complete land preparation for a region in 22 days on average. Transplanters were not used in the region, even though transplanting seedlings is a critical, labor-intensive activity; farmers preferred to save labor by broadcasting seeds rather than transplanting. Combine harvesters had spread throughout the Delta and were provided on a contract basis. The average density was two harvesters per 100 ha. With a capacity of $3 \mathrm{ha} /$ day, this number of machines could complete the harvest in 17 days. As the window for harvesting is 7-10 days, harvesters had to be contracted from other provinces to augment the local supply of this service.

Considering the Mekong Delta as a whole, the Ministry of Agriculture and Rural Development (MARD) reported that there were 12,300 harvesters in 2011, including 8600 combine harvesters (obviating the need for threshers). Given a harvesting capacity of $3-5$ ha/day, there were clearly too few harvesters to service the 1.5 million hectares of rice land-at 4 ha/day

Table 18.3 Availability of machinery services in study communes in $2011(n=20)$

\begin{tabular}{llll}
\hline Indicator & Han Giang & An Giang & Average \\
\hline $\begin{array}{l}\text { Mean no. of households per commune owning } \\
\text { two-wheel tractors }\end{array}$ & 387 & 456 & 421.5 \\
No. of two-wheel tractors per 100 ha & 2.3 & 3.7 & 3.0 \\
Mean no. of transplanters per commune & - & - & - \\
No. of transplanters per 100 ha & - & - & - \\
Mean no. of harvesters per commune & 271 & 345 & 308 \\
No. of harvesters per 100 ha & 1.5 & 2.5 & 2.0 \\
Mean no. of dryers per commune & 3.1 & 2.6 & 2.9 \\
No. of dryers per 100 ha & 0.3 & 0.2 & 0.2 \\
\hline
\end{tabular}

Source: Survey of staff in 20 communes, 2012 
the harvest would take at least 30 days, not counting movement between fields and breakdowns. The state has supporting policies for acquiring agricultural machinery, especially interest rate support. However, the technical and financial capacity of machinery manufacturers to expand in Vietnam is limited, hence so is the supply of more efficient and affordable harvesters.

The cost to farmers for harvesting services was very high and varied with the stage of the harvest and the type of harvester. The normal fee was VND 260,000-400,000 per $1000 \mathrm{~m}^{2}$, but at the end of the harvest, when farmers were more desperate, the fee was VND 350,000-450,000 per $1000 \mathrm{~m}^{2}$. The lack of harvesting services in high season in a given location meant that producers hired services from other localities, but they had to access these services through an intermediary who charged VND 15,00020,000 per $1000 \mathrm{~m}^{2}$.

The provision of drying services for the harvested paddy was the most limiting constraint in the production system in the study area, especially with the spread of combine harvesters. According to the survey of 20 communes, there were only 2.9 dryers per commune on average, giving a density of only 0.2 dryers per 100 hectares. At an average yield of $6 \mathrm{t} / \mathrm{ha}$, this implied a total harvest of $3000 \mathrm{t} /$ dryer. Yet most of these dryers were owned by the local rice mills with a very low capacity of $15 \mathrm{t} /$ day, requiring 200 days for one crop. This had led to a situation in which, during peak season, many farmers had to sell "wet paddy" at a discount because they did not have access to a dryer or drying yard.

(3) Agricultural extension and training. Extension and training for rice farmers in the Delta region almost all take place through farmer groups or cooperatives. Farmers do not pay for the training because they are funded by the state and the private sector; in the survey, $21 \%$ of farmers were only trained by a private-sector actor, $7 \%$ were only trained by a state agency, and $72 \%$ were trained by both. The survey of villages and communes showed that $17.7 \%$ of communes had a cooperative and $14.4 \%$ had a cooperative or farmer group related to rice production (Table 18.4). The average number of extension officers in each commune was 0.6 , meaning that many communes did not have regular access to this source of technical advice.

\section{Producers}

The survey sampled rice producers from three different size classes (Table 18.5). Interestingly, household size and the number of family 
Table 18.4 Extension offices and cooperatives in communes

\begin{tabular}{lccc}
\hline Content & Hau Giang & An Giang & Average \\
\hline Average no. of extension offices per commune & 0.5 & 0.7 & 0.6 \\
\% of communes with farmer cooperatives & 15.3 & 20.2 & 17.7 \\
\% of communes with cooperatives dealing in rice & 10.3 & 18.4 & 14.4 \\
\hline
\end{tabular}

Source: Surveys, 2012

Table 18.5 Characteristics of rice producers in study area $(n=300)$

\begin{tabular}{lllll}
\hline Item & \multicolumn{3}{l}{ Farm size category } & \\
\cline { 2 - 5 } & $\begin{array}{l}\text { Small } \\
(<1 \text { ha }) \\
(\mathrm{n}=87)\end{array}$ & $\begin{array}{l}\text { Med. } \\
(1-2 \text { ha }) \\
(\mathrm{n}=124)\end{array}$ & $\begin{array}{l}\text { Large } \\
(>2 \text { ha }) \\
(\mathrm{n}=89)\end{array}$ & $\begin{array}{l}\text { All } \\
(\mathrm{n}=300)\end{array}$ \\
\hline Household size (persons) & 5.3 & 4.0 & 3.0 & 4.0 \\
No. of workers/household & 3.2 & 2.2 & 1.5 & 2.3 \\
Paddy area (ha) & 0.67 & 1.42 & 5.20 & 2.45 \\
Area rented (ha) & 0.50 & 1.32 & 2.53 & 1.45 \\
Paddy yield (t/ha) & 6.0 & 6.2 & 6.2 & 6.1 \\
Farm-gate price $\left(\mathrm{VND} \times 10^{3} / \mathrm{kg}\right)$ & 5211 & 5226 & 5258 & 5232 \\
Gross revenue $\left(\mathrm{VND} \times 10^{3} / \mathrm{ha}\right)$ & 31,110 & 32,140 & 32,600 & 31,915 \\
Production cost $\left(\mathrm{VND} \times 10^{3} / \mathrm{ha}\right)$ & 22,543 & 21,057 & 20,750 & 21,450 \\
Net income (VND $\left.\times 10^{3} / \mathrm{ha}\right)$ & 8567 & 11,083 & 11,850 & 10,465 \\
\hline
\end{tabular}

Source: Producer survey, 2012

Note: USD 1 = VND 22,727 (11 August 2017)

workers decreased with increasing farm size, perhaps reflecting outmigration from the larger, more prosperous farm-households which also were more mechanized and employed hired labor. Obviously, the paddy area increased with farm size, with small and medium farmers renting in most of their paddy land $(75 \%$ and $93 \%$, respectively) while large farmers rented in under half their paddy land on average. Despite these differences, the productivity of the three groups did not differ greatly. The yield of the medium and large farmers was only slightly higher than that of the small farmers. This, combined with a slight upward trend in farm-gate price with farm size, perhaps reflecting the production of higher-value varieties on larger farms, meant that gross revenue also increased slightly with farm size. With a slight decreasing trend in production cost per ha with farm size, the net income per ha showed a more significant increase across the 
size classes, with medium farms earning 30\% more than small farms, and large farms earning 38\% more.

Farmers sold their paddy in different forms according to the time of sale. At harvest time, $75 \%$ of farmers sold wet paddy, that is, not dried to the required moisture content, and $25 \%$ sold dried paddy. Although the government encourages farmers to sell dried paddy to increase their profits, the cost of investing in drying equipment is large. Most producers had to accept the loss of profit from selling wet paddy, incurring a price difference of VND $900-1000 / \mathrm{kg}$. In the months between harvests, all paddy sold was dried, this paddy coming from households with higher storage capacity.

Traders acquired $93 \%$ of the farmers' paddy (Fig. 18.2). However, the relationship between traders and farmers was quite loose. Trading through paddy brokers, who acted as local collectors, accounted for $55 \%$ of purchases. Only $4 \%$ of the paddy produced was purchased directly by millers, who operated in the same locality as the farmers from whom they bought. The polishing/exporting firms purchased directly only $3 \%$ of paddy produced. In acquiring paddy from farmers, $85 \%$ of buyers paid a deposit at the rate of $20-25 \%$ of the total value of paddy acquired, $10 \%$ made a "definitive purchase" (i.e., paid in full at the time of acquisition), and $5 \%$ paid only after the paddy was delivered to the mill. Thus, the majority of paddy sold was subject to flexible arrangements between farmers and traders.

\section{Traders}

Traders were a key link in the value chain as $93 \%$ of paddy produced was sold to these actors (Fig. 18.2). The traders surveyed were mostly small, multi-enterprise businesses without warehouses or shops (Table 18.6). They transported paddy by boat, with an average capacity of $26 \mathrm{t}$ (Fig. 18.3). On average, each trader purchased 113 t of paddy per month from farmers. Only $8 \%$ of traders interviewed represented a particular rice mill; the majority of the traders operated independently and were not bound to particular farmers or buyers. There was no overarching organization of traders and no state policy that directly impacted on them.

About $13 \%$ of paddy bought by traders was sold to rice mills in the region (Fig. 18.2). Another 11\% was put through the mills for milling and polishing and then sold as finished rice to wholesalers and retailers. 
Table 18.6 Characteristics of rice traders in study area $(n=60)$

\begin{tabular}{ll}
\hline Characteristic & Value \\
\hline Average number of employees & 2.2 \\
Number of years in operation (years) & 9.7 \\
Traders who began as farmers (\%) & 20 \\
Traders linked to a single rice mill (\%) & 8.3 \\
Traders with storehouse, shops (\%) & 1.7 \\
Traders owning boats/ships (\%) & 100 \\
Average number of boats & 1 \\
Average tonnage of boats & 25.9 \\
Average value of boat (VND $\left.\times 10^{3}\right)$ & 173,000 \\
Average paddy volume purchased $(\mathrm{t} /$ month) & 113 \\
\hline
\end{tabular}

Source: Trader survey, 2012

Note: USD 1 = VND 22,727 (11 August 2017)

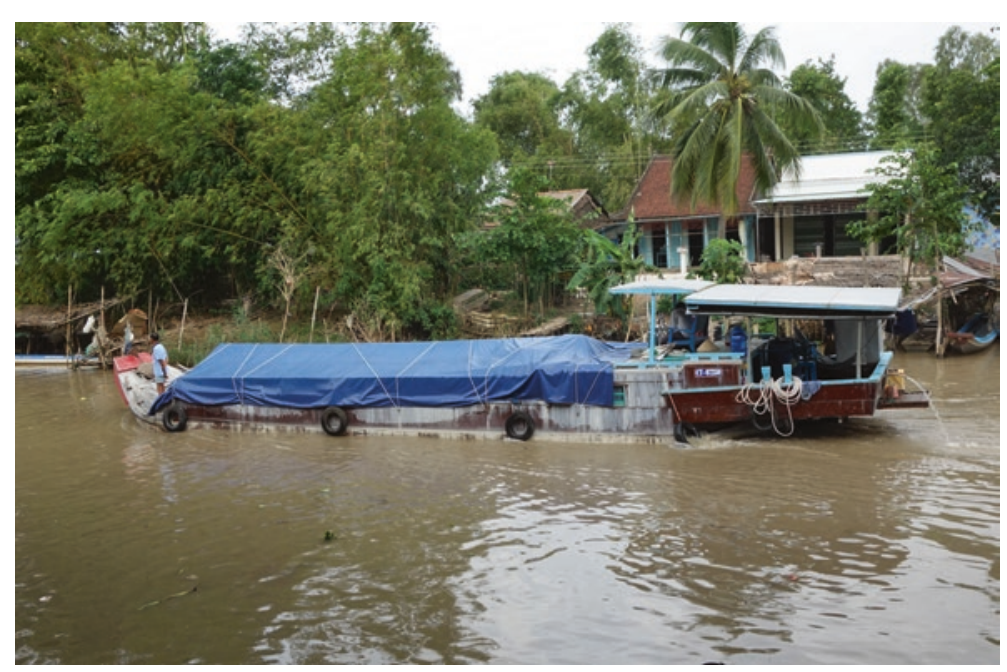

Fig. 18.3 Trader transporting paddy in Can Tho Province. (Photo: Dao The Anh)

However, most paddy (69\%) was put through first-stage rice mills and sold in bulk to large export firms for polishing, bagging, and shipment overseas.

In performing these transactions, $71 \%$ of traders sold through "rice intermediaries" who linked them to the factories. The appearance of such 
intermediaries between farmers, traders, and millers helped the marketing system to operate, but it created a long chain, adding to costs and reducing the direct links between actors. About $40 \%$ of traders received an advance deposit from the factories in order to buy paddy and $60 \%$ only received payment after the paddy was delivered and so had to provide their own working capital.

\section{Processors}

Processing factories could be involved in any combination of de-husking, removing the rice bran, and polishing. However, as shown in Table 18.7, the processes were distributed quite differently among the four types of processor in the Mekong Delta. Small mills mainly produced white rice for local consumption on a daily basis, whereas medium and large mills were mainly engaged in the de-husking process, supplying brown rice to the large polishing factories, though $25 \%$ of the large mills performed all the processes through to polishing (Fig. 18.4). The large export firms mainly acquired de-husked or de-branned rice from the mills for polishing (92.5\%).

The owners of the processing firms did not differ greatly in age or education, though the miller-polishers had more years of education on average (Table 18.8). The larger businesses had more experience in the industry (averaging $11-15$ years) than the small millers (6 years). All of

Table 18.7 Types of rice processor in study area $(n=70)$

\begin{tabular}{|c|c|c|c|c|c|}
\hline \multirow[t]{2}{*}{ Process } & \multirow[t]{2}{*}{ Product } & $\begin{array}{l}\text { Small mills } \\
(\mathrm{n}=10)\end{array}$ & $\begin{array}{l}\text { Med. mills } \\
(\mathrm{n}=15)\end{array}$ & $\begin{array}{l}\text { Large mills } \\
(\mathrm{n}=4)\end{array}$ & $\begin{array}{l}\text { Miller-polisher } \\
(\mathrm{n}=41)\end{array}$ \\
\hline & & \multicolumn{4}{|c|}{$\%$ of processors in each category } \\
\hline De-husking & $\begin{array}{l}\text { Brown } \\
\text { rice }\end{array}$ & 0 & 72.7 & 75.0 & 0 \\
\hline Polishing only & $\begin{array}{l}\text { Polished } \\
\text { rice }\end{array}$ & 12.5 & 0 & 0 & 92.5 \\
\hline $\begin{array}{l}\text { De-husking, } \\
\text { de-branning }\end{array}$ & White rice & 87.5 & 27.3 & 0 & 0 \\
\hline $\begin{array}{l}\text { De-husking, } \\
\text { de-branning, polishing }\end{array}$ & $\begin{array}{l}\text { Polished } \\
\text { rice }\end{array}$ & 0 & 0 & 25.0 & 7.5 \\
\hline Total & & 100 & 100 & 100 & 100 \\
\hline
\end{tabular}

Source: Processor survey, 2012

Note: USD l = VND 22,727 (11 August 2017) 


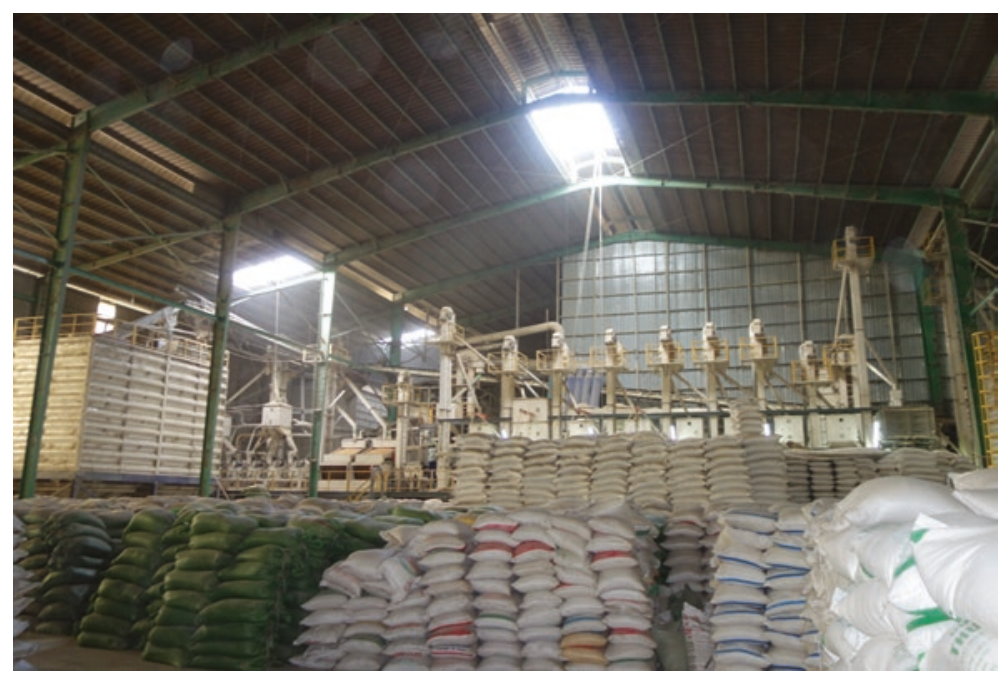

Fig. 18.4 Large rice mill in Can Tho Province. (Photo: Dao The Anh)

Table 18.8 Characteristics of rice processors in study area $(n=70)$

\begin{tabular}{lllll}
\hline Characteristic & $\begin{array}{l}\text { Small mills } \\
(\mathrm{n}=10)\end{array}$ & $\begin{array}{l}\text { Med. mills } \\
(\mathrm{n}=15)\end{array}$ & $\begin{array}{l}\text { Large mills } \\
(\mathrm{n}=4)\end{array}$ & $\begin{array}{l}\text { Miller-polisher } \\
(\mathrm{n}=41)\end{array}$ \\
\hline Age of owner (years) & 42 & 49 & 45 & 46 \\
Education of owner (years) & 8.4 & 9.9 & 9 & 12.7 \\
Years of business & 6 & 11 & 15 & 12 \\
Private firm (\%) & 100 & 100 & 100 & 75.6 \\
State joint-stock firm $(\%)$ & 0 & 0 & 0 & 12.2 \\
Private joint-stock firm $(\%)$ & 0 & 0 & 0 & 12.2 \\
Area of factory $\left(\mathrm{m}^{2}\right)$ & 87 & 1550 & 2500 & 4825 \\
Capacity of factory $(\mathrm{t} / \mathrm{hr})$ & 0.2 & 3.8 & 9.6 & 20.8 \\
Value of factory $\left(\mathrm{VND} \times 10^{3}\right)$ & 111,000 & $2,420,000$ & $4,000,000$ & $2,975,610$ \\
Operating capital $\left(\mathrm{VND} \times 10^{3}\right)$ & 4612 & $1,353,346$ & $1,325,000$ & $46,471,073$ \\
Rice throughput $(\mathrm{t} / \mathrm{month})$ & 48 & 2268 & 6768 & 13,791 \\
\hline
\end{tabular}

Source: Processor survey, 2012

Note: USD 1 = VND 22,727 (11 August 2017)

the rice millers were private firms, whereas a quarter of the miller-polisher businesses were private or state joint-stock companies. The different functions of the four types of processor corresponded to different scales and operating capacities, as seen in the area and capacity of the factory 
and the fixed and operating capital tied up in the business (Table 18.8). Hence, the throughput of rice varied from $50 \mathrm{t} / \mathrm{month}$ for the small rice mills to $14,000 \mathrm{t} /$ month for the large milling, polishing, and exporting firms.

The rice mills mainly focused on providing a de-husking service for the rice traders, accounting for $80 \%$ of their output (Fig. 18.2). Purchasing paddy for milling accounted for $17 \%$ of millers' output, including $13 \%$ sold in bulk to exporters and only $4 \%$ sold to wholesalers and retailers. The polishing/exporting businesses were the main actors supplying rice to the domestic wholesale and retail market ( $15 \%$ of total rice output from the region, or half the domestic supply) and all the export market (70\% of total rice output) through export contracts. However, not all polishing factories had the right to export under the government's Decree 109 (only 150 enterprises in Vietnam have an export license for rice). Such factories either sold rice to firms that were able to export or bought rice from these enterprises to enable them to export.

\section{WhOLESALERS AND RETAILERS}

Focusing on the domestic market, the main actors supplying rice to consumers were the wholesalers, traditional retailers, and modern retailers.

The wholesalers were on average medium-sized enterprises with about $60 \mathrm{~m}^{2}$ of storage space and a throughput of $68 \mathrm{t} / \mathrm{month}$, requiring working capital of around USD 25,000 (Table 18.9). They bought half their supplies from the polishing factories, 37\% from traders, and $13 \%$ from rice millers. Most of their sales $(85 \%)$ were to traditional retailers.

Table 18.9 Characteristics of rice wholesalers and retailers in study area $(n=180)$

\begin{tabular}{llll}
\hline Characteristic & $\begin{array}{l}\text { Wholesalers } \\
(\mathrm{n}=50)\end{array}$ & $\begin{array}{l}\text { Traditional } \\
\text { retailers }(\mathrm{n}=85)\end{array}$ & $\begin{array}{l}\text { Modern retailers } \\
(\mathrm{n}=45)\end{array}$ \\
\hline Age of owner (years) & 42 & 32 & - \\
Number of employees & 2.1 & 1.6 & 0.7 \\
Length of operation (years) & 8.7 & 8.9 & 6.3 \\
Floor space for rice stocks $\left(\mathrm{m}^{2}\right)$ & 60.7 & 17.9 & 10.6 \\
Operating capital $\left(\mathrm{VND} \times 10^{3}\right)$ & 532,600 & 39,133 & - \\
Volume of rice sold $(\mathrm{t} / \mathrm{month})$ & 68 & 1.5 & 23.5 \\
\hline
\end{tabular}

Source: Wholesaler/retailer survey, 2012

Note: USD l = VND 22,727 (11 August 2017) 
Sales to other wholesalers accounted for $5 \%$ and direct sales to consumers and small shops for $8 \%$. Very little was sold to modern retailers. About $92 \%$ of the wholesale product provided to retailers was sold in plastic packages of $50-55 \mathrm{~kg}$. Of the packaged rice, $60 \%$ did not have clear information on the packaging, $26 \%$ had factory information and a brand mark, and $14 \%$ had only factory information.

Each traditional marketplace in the Delta had on average 6.7 traditional retailers operating small stores with about $18 \mathrm{~m}^{2}$ of storage space for rice (Table 18.9). Thus, retailers were spread widely across the region, each selling only $1.5 \mathrm{t} / \mathrm{month}$ on average, requiring working capital of under USD 2000. Almost all traditional retailers surveyed (99\%) sold rice in loose form, providing customers with plastic bags at the point of sale. Although the rice was packaged and labeled in 50-55 kg packs when bought from the wholesaler, selling loose rice was a feature of traditional retailing, enabling consumers to better assess the product in the market.

Modern retailers (supermarkets, food stores) were central actors in the government's rice price stabilization policy. However, rice was not the main item for these retailers, so they did not exploit its full potential. On average, only $10 \mathrm{~m}^{2}$ were allocated for rice stocks, and there were no employees dedicated to the rice product (Table 18.9). The modern retailers sold almost all their rice (92\%) in plastic packages, including $2 \mathrm{~kg}, 5 \mathrm{~kg}$, and $10 \mathrm{~kg}$ sizes. They also paid special attention to the brand mark and product information- $97 \%$ of bags had this labeling. This meant that the price of the same type of rice from a modern retailer was much higher than from a traditional retailer, hence the number of consumers buying rice from modern retailers was low, most consumers still relying on traditional retailers. Nevertheless, modern retailers averaged sales of $24 \mathrm{t} /$ month.

\section{Marketing Margins in the Rice Value Chain}

The costs of producing, processing, and delivering rice to domestic consumers in the Mekong Delta were assessed. The average cost of rice production was obtained from the farmer survey (Table 18.10). It can be seen that there was a little variation in the per-hectare cost of production between farm size classes. Small farmers incurred somewhat more expenditure for fertilizers and pesticides than large farmers, and large farmers paid more interest on working capital, but the distribution of cost items and the total costs per ha (both paid-out or cash costs and imputed costs) were not significantly different. On average, total production costs were 
about VND 21.5/million/ha (USD 950/ha) and VND 3.5 million/t of paddy (USD $155 / \mathrm{t}$ ). At a milling conversion rate of $75 \%$, the production cost per kg of milled, polished rice was VND 4688 (USD 0.20).

To analyze the costs and margins along the domestic and export value chains, selling and purchase prices were converted into the equivalent weight of rice and the value of one actor's output was taken as the input cost of the next actor in the chain (Table 18.11). For farmers, input costs were taken to be the costs of seed, fertilizers, and pesticides, while other paid-out and imputed costs were classified as "incremental costs". The total value added in the domestic value chain was VND $3303 / \mathrm{kg}$ (USD $0.15 / \mathrm{kg}$ ), with nearly $70 \%$ of this total coming from the post-milling actors (polishers, wholesalers, and retailers). In the export value chain, the total value added was VND $2131 / \mathrm{kg}$ as the chain was not followed through to the foreign buyers.

In both chains, the margins obtained by each actor represented a return over operating costs of $5-10 \%$, except for the millers, who achieved returns

Table 18.10 Cost of paddy rice production $\left(\mathrm{VND} \times 10^{3}\right.$ per ha)

\begin{tabular}{|c|c|c|c|c|c|c|c|c|}
\hline \multirow[t]{2}{*}{ Item } & \multicolumn{2}{|c|}{ Small farm } & \multicolumn{2}{|l|}{$\begin{array}{l}\text { Medium } \\
\text { farm }\end{array}$} & \multicolumn{2}{|c|}{ Large farm } & \multicolumn{2}{|l|}{$A l l$} \\
\hline & Mean & $\%$ & Mean & $\%$ & Mean & $\%$ & Mean & $\%$ \\
\hline Seed & 1619 & 7 & 1684 & 8 & 1489 & 7 & 1554 & 7 \\
\hline Fertilizers & 8400 & 37 & 7710 & 37 & 6280 & 30 & 7460 & 35 \\
\hline Pesticides & 1023 & 5 & 1051 & 5 & 889 & 4 & 987 & 5 \\
\hline Irrigation & 185 & 1 & 195 & 1 & 180 & 1 & 187 & 1 \\
\hline Wages & 1587 & 7 & 1877 & 9 & 1296 & 6 & 1589 & 7 \\
\hline Machine hire & 505 & 2 & 505 & 2 & 454 & 2 & 488 & 2 \\
\hline Land rental & 710 & 3 & 680 & 3 & 600 & 3 & 667 & 3 \\
\hline Marketing & 1594 & 7 & 1494 & 7 & 1393 & 7 & 1494 & 7 \\
\hline Interest & 1343 & 6 & 492 & 2 & 3511 & 17 & 1824 & 9 \\
\hline Paid-out costs & 16,966 & 75 & 15,688 & 74 & 16,092 & 77 & 16,250 & 76 \\
\hline Family labor & 2743 & 12 & 2865 & 14 & 2918 & 14 & 2841 & 13 \\
\hline Depreciation & 2835 & 13 & 2505 & 12 & 1740 & 8 & 2361 & 11 \\
\hline Total costs & 22,543 & 100 & 21,057 & 100 & 20,750 & 100 & 21,450 & 100 \\
\hline Yield (t/ha) & 6.0 & & 6.2 & & 6.2 & & 6.1 & \\
\hline Cost of paddy $\left(\mathrm{VND} \times 10^{3} / \mathrm{t}\right)$ & 3757 & & 3396 & & 3347 & & 3516 & \\
\hline Cost of rice (VND/kg) & 5009 & & 4528 & & 4463 & & 4688 & \\
\hline
\end{tabular}

Source: Producer survey, 2012

Note: USD I = VND 22,727 (11 August 2017) 
Table 18.11 Costs and margins in domestic and export rice value chains (VND per kg rice)

Farmers Traders Millers Polishers Wholesalers Retailers Total

\begin{tabular}{llllllll}
\hline $\begin{array}{l}\text { Domestic market } \\
\text { Selling price }\end{array}$ & 5232 & 5925 & 6780 & 7994 & 10,118 & 12,700 & \\
Input cost & 2213 & 5232 & 5925 & 6780 & 7994 & 10,118 & \\
Incremental cost & 2534 & 246 & 754 & 533 & 1423 & 1694 & \\
Total variable cost & 4747 & 5478 & 6679 & 7313 & 9417 & 11,812 & \\
Value added & 485 & 447 & 101 & 681 & 701 & 888 & 3303 \\
Value added/cost (\%) & 10 & 8 & 2 & 9 & 7 & 8 & \\
\% of total value added & 15 & 14 & 3 & 21 & 21 & 27 & 100 \\
Export market & & & & & & & \\
Selling price & 5232 & 7019 & 6780 & 7994 & 9555 & & \\
Input cost & 2213 & 5232 & 5925 & 6780 & 7994 & & \\
Incremental cost & 2534 & 1345 & 754 & 533 & 1139 & & \\
Total variable cost & 4747 & 6577 & 6679 & 7313 & 9133 & & \\
Value added & 485 & 442 & 101 & 681 & 422 & & \\
Value added/cost (\%) & 10 & 7 & 2 & 9 & 5 & & \\
$\%$ of total value added & 23 & 21 & 5 & 32 & 20 & & \\
\hline
\end{tabular}

Source: Surveys, 2012

Note: USD l = VND 22,727 (11 August 2017)

of only $2 \%$ (Table 18.11). Farmers obtained the highest return of $10 \%$ and contributed $15 \%$ of value added in the domestic chain and $23 \%$ in the (truncated) export chain. Thus, there was no indication that any actor in the chain was realizing excessive margins, reflecting a large number of actors at each stage and a competitive market overall.

\section{Impact of State Policies on Rice Value Chain}

Since 1975, rice policy in Vietnam has mainly focused on increasing productivity through the use of short-term, high-yielding varieties and increased fertilizer use. As a consequence, rice yields in Vietnam as a whole increased from $2.5 \mathrm{t} / \mathrm{ha}$ in 1975 to $5.8 \mathrm{t} / \mathrm{ha}$ in 2015 . Moreover, the cropping intensity in favorable regions such as the Mekong Delta has increased, such that about $27 \%$ of the total rice area is cultivated three times a year. However, increased productivity has resulted in the predominance of low-quality rice in the export market. Moreover, the incidence of poverty among small rice farmers remains high, because the 
value of rice production per unit area is very low and has not improved for some time (Jaffee et al. 2012; Thu 2013).

In 2010, the government issued Resolution No. 63/NQ-CP on ensuring food security, stipulating that farmers must be assured a $30 \%$ profit. This policy was intended to discourage diversification out of rice production by boosting farmer returns. However, few rice processing enterprises buy paddy directly from farmers. Traders dominate this stage $(93 \%$ of paddy purchases, Fig. 18.2) and transmit prices from the mills, earning a return of $7-8 \%$ compared with the farmers' $10 \%$ (Table 18.8 ). Thus, it is infeasible to enforce this policy.

With regard to rice exports, Decree No. 109 of 2010 introduced regulations about the enterprises allowed to export rice, namely, those having a factory with a capacity of over $10 \mathrm{t}$ /hour, storage capacity of over 5000 $t$, and reserves in circulation of over $10 \%$ of the volume of rice that they exported in the previous six months. This led to the formation of informal networks among firms as the exporters that did not meet the conditions had to buy additional rice from other enterprises. However, the decree did not provide any benefit to farmers. Export prices are not listed; hence an increase in prices mainly benefits the exporters as farmers do not have the information or means to increase their margins. Currently, the government is preparing to issue an alternative policy whereby storage regulations will be replaced by product quality regulations. This will remove the limit on the number of businesses allowed to export, encouraging small businesses to export high-quality rice. Exporters will also be encouraged to develop contract farming areas, promoting higher rice quality.

The price stabilization policy has not been clear or consistent. The state does not have the capital to purchase and store rice, so reserves are required to be held by exporters with the support of state-subsidized loans to ensure rice prices for farmers. However, this mechanism is not suitable for the exporters because they are forced to use their own capital for the purchase of stocks and temporary storage, increasing their costs and reducing their competitiveness in the export market. The price stabilization mechanism does not distinguish between the objectives of food security, price stability, and the profitability of the exporters, yet an effective policy requires the clear separation of objectives to ensure benefits to all parties.

Provincial policies in the Mekong Delta have mainly focused on advising farmers to cultivate three crops of rice a year and concentrate on varieties to improve rice quality (though the quality of rice in the third season is mostly low). This policy has run into problems because the focus is only 
on rice producers. When farmers produce better-quality varieties, the market (traders and processors) still demands the low-quality varieties that form the bulk of the export trade, resulting in a situation in which farmers cannot sell their rice. In addition, high-quality rice varieties tend to have lower yields but the price premium is only VND $200 / \mathrm{kg}$ over normal rice, reducing farmers' profit. A good example of this contradiction is in An Giang Province, where the government discourages the planting of IR50404. However, this variety has high yield, is easy to grow, has fewer diseases, and is in high demand in the export market, so it is planted on up to 107,000 ha, accounting for 17\% of the total cultivated area in An Giang.

Improving rice quality is one of the central strategies of the government. Accordingly, in 2013, the Ministry of Agriculture and Rural Development (MARD) approved the National Rice Product Development Project with two key tasks - to improve the competitiveness of rice products and enhance the return to actors in the value chain. In addition, in 2016, MARD issued a plan to restructure the rice sector to 2020 - "Improving the efficiency of rice production and trade in Vietnam" (Decision No. 1898/QD-BNN-TT). This project is intended to (1) improve rice quality; (2) upgrade organization, policies, and institutions to improve value chain operations; (3) improve harvesting and processing technology; (4) promote sustainable market development; (5) facilitate environmental protection and adaptation to climate change; and (6) ensure food and nutrition security.

\section{CONCLUSION}

The rice value chain in the Mekong Delta is a large and complex system, successfully linking about 1.5 million small-scale rice farmers cultivating over 4 million ha per year to large numbers of traders, processors, wholesalers, retailers, and exporters. About $30 \%$ of production enters the domestic market and $70 \%$ is exported, accounting for over $90 \%$ of national exports.

There are many intermediaries in the domestic rice value chain in the Mekong Delta. Input suppliers are widely dispersed in the region, providing seeds, fertilizers, and other inputs competitively to small, medium, and large farmers. Agricultural extension and training are provided by both public and private sectors through farmer groups. The region has seen rapid mechanization, with the spread of two-wheeled tractors and combine harvesters, the latter mainly provided through contract services, 
including from outside the region. Despite the high fees (up to USD $180 / \mathrm{ha}$ ), the labor-saving benefit of mechanical harvesting has ensured almost universal adoption. However, there is limited availability of driers at the farm or commune level, meaning that most farmers sell wet paddy at a discount, which then has to be dried at the mills.

Almost all the harvested rice crop is sold to local traders at the farm gate. These are small, independent operators who transport paddy by boat to the rice mills. However, they are mostly linked to processors through intermediaries who frequently advance funds to the traders to buy paddy. Most paddy goes through small mills that produce white rice, some of which are sold directly to domestic wholesalers but most of which go to exporters for polishing and bagging.

Wholesalers are medium-sized enterprises, buying from polishing factories, traders (after they have arranged milling), and directly from millers. Most of their sales are to traditional retailers who are spread widely across the region, operating small stores. The rice is sold loose and packaged after purchase. Modern retailers sell pre-packaged and labeled rice at higher prices than traditional retailers, and their share of the domestic market is low.

None of the actors in the domestic value chain appears to gain an excessive margin, with returns on working capital mostly in the range $7-10 \%$, though small-scale millers average a lower return. It is unlikely that market efficiency could be improved through any structural intervention, given the high degree of competition at each stage. Rather, better forms of credit to enable producers (perhaps as farmer groups), service providers, and processors to invest in improved technology may do more to improve the efficiency of the value chain. Government policies need to consider the whole chain rather than focusing on one class of actors, for example, by encouraging farmers to cultivate high-quality varieties that are not in demand.

In order to increase the value and competitiveness of the rice value chain in the Mekong Delta, the government should implement a policy to promote the quality of rice through contract farming between cooperatives and private enterprises based on quality standards. The export policy of Decree 109 based on the capacity of the mill was not successful because of a lack of focus on quality. A revised policy should open the export market to private enterprises that obtain export contracts based on quality. 


\section{Notes}

1. This chapter is based on research supported under the Asian Development Bank TA-7648 Regional-Research and Development Technical Assistance (R-RDTA). A fuller version of the survey results and analysis has been reported in Rice Value Chain Study in the Mekong River Delta, Viet Nam by Dao The Anh, Thomas Reardon, Kevin Chen, Thai Van Tinh, Vu Nguyen, Nguyen Ngoc Vang, Nguyen Van Thang, and Le Nguyen Doan Khoi and subsequently incorporated in Rice Value Chains in China, India, Lao PDR, and Viet Nam: 2012 Survey Results, Interpretations, and Implications for Policy and Investment, a report submitted by the International Food Policy Research Institute to the Asian Development Bank, 15 September 2013.

2. Department of Agriculture and Rural Development, An Giang Province, various years. Report on Agricultural Activities in An Giang Province; Department of Agriculture and Rural Development, Hau Giang Province, various years. Report on Agricultural Activities in Hau Giang Province.

3. This may mean that farmers purchased new seeds every few years and then retained seeds from several crops before replenishing their stock.

\section{REFERENCES}

Chen, K., Reardon, T., Dao The Anh, Wong, L., Huang, Z., Das Gupsta, S., and Wang, J., 2013. Rice Value Chain in China, India, Lao PDR and Vietnam: 2012 Survey Results, Interpretations, and Policies Implications for Investment. Final Report submitted by IFPRI for ADB (TA-7648 REG Project, Component 2). Available at http://www.ifpri.org/publication/rice-value-chains-chinaindia-lao-pdr-and-viet-nam-2012-survey-results-interpretations.

General Statistics Office of Vietnam (GSOV), 2013. Statistical Yearbook of Vietnam, 2013. Hanoi: Statistical Publishing House.

Jaffee, S., Nguyen Van Sanh, Dao The Anh, and Nguyen Do Anh Tuan, 2012. Vietnam Rice, Farmers and Rural Development: From Successful Growth to Sustainable Prosperity. Hanoi: World Bank.

Kaplinsky, R., and Morris, M., 2000. A Handbook for Value Chain Research. Ottawa: IDRC.

Purcell, T., 2010. Rice Production in Cambodia-Trends in Production and Productivity and Opportunities for Improvement. Phnom Penh: Agricultural Development International.

Thu Huong, 2013. Vietnam Rice Development Policy Shortcomings. Vietnam Economic Times, 8 April 2013. 
Tran Tien Khai, 2010. Export policies in Vietnam and problems that need to be adjusted. In Proceedings of the Mekong River Socio-Economic Sciences and Regional Development Conference, Can Tho.

VFA, 2012. Annual Activity Report of 2012. Hanoi: Vietnam Food Association.

Vo Thi Thanh Loc, and Nguyen Phu Son, 2011. Rice value chain analysis in the Mekong Delta. Cantho University Scientific Magazine, pp. 96-108.

Open Access This chapter is licensed under the terms of the Creative Commons Attribution 4.0 International License (http://creativecommons.org/licenses/ by $/ 4.0 /$ ), which permits use, sharing, adaptation, distribution and reproduction in any medium or format, as long as you give appropriate credit to the original author(s) and the source, provide a link to the Creative Commons licence and indicate if changes were made.

The images or other third party material in this chapter are included in the chapter's Creative Commons licence, unless indicated otherwise in a credit line to the material. If material is not included in the chapter's Creative Commons licence and your intended use is not permitted by statutory regulation or exceeds the permitted use, you will need to obtain permission directly from the copyright holder.

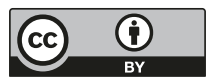

